\title{
Renewed Conceptions of Traditions in Hungarian Gastronomy via Example of Orange Wines
}

\author{
Zsuzsanna Bene \\ University of Miskolc, Miskolc, Hungary
}

\begin{abstract}
Nowadays in the range of gastronomic trends, there are important roles of local high quality basic materials, organic products, culinary delight of food-drink pair, and the fifth basic taste so called umami. There are technical new methods and raw materials coming to Hungary but it is a very important task to find the suitable balance in using them to colour nation cuisine. The appearance of new trends and new guidelines is more and more characteristic of the world's wine-making today. A very important role is played by innovation, respecting the existence of traditions, the roots of grape producing, and wine-making cultures. Over the last two years, skin-contact fermented white wines, the so-called orange wines, have attracted international attention in wine sector and in gastronomy. Orange wines owning high alcohol content and spicy taste are being able to find good pairs for them in menu. By the way, they are not well-known and should be taught for chefs and consumers too. Hungarian consumers often have neofobia, they are afraid of eating or drinking new type of foods and that is why renewed conceptions of traditions have important role in the national cuisine.
\end{abstract}

Keywords: culinary trends, food neofobia, gastrotourism, orange wine

\section{Introduction}

Hungarian cuisine has strong traditional root, taking care of tradition and respect are very important in the national gastronomy but joining to continuous renewed conceptions is unavoidable. Hungarian cuisine should become more healthy and precious by using new technical methods, new basic materials, and taking new food-drink pair.

Orange wines are skin-contact fermented white wines with very special colour, taste, and characters. In the case of these wines, the normal white wine making procedure is not followed, there is a long fermented time on skin, pressed and put into special vessels to age. There are two very important facts, one is using the natural grape without chemical treatments and the second one is, letting micro-oxidization happen through the clay giving special colour similar to "orange" and an unique rich taste which is unusual in the case of white wines (Bene \& Piskóti, 2017).

The present paper has three objectives:

(i) Collect a selection of Hungarian skin-contact fermented white wines and with the aid of profile analysis doing a wine aroma wheel to give main characteristic features of these wines to find suitable food-and-drink pair;

Zsuzsanna Bene, Ph.D., associate professor, Institute of Marketing and Tourism, Faculty of Economics, University of Miskolc, Miskolc, Hungary.

Correspondence concerning this article should be addressed to Zsuzsanna Bene, 50. Felso str., Bodrogkeresztur H-3916, Hungary. 
(ii) Determine what Hungarian dishes pair well matches with orange wine;

(iii) Find good positional place for orange wines as a new gastronomy trend in the Hungarian gastrotourism.

\section{Literature Review}

\section{Hungarian Gastronomic Traditions}

The formation of Hungarian cuisine is connected with the history of Hungarian nation. The ancient Hungarian meals covered the five elements: fire, water, soil, wood, and metal, and harmony of the five tastes: sweet, sour, salty, bitter, and hot (Tusor, 2005). All the time, the attainment of harmony was standing in the limelight. In the early periode, Hungarian people rather cooked than fried.

There were many effects on Hungarian cuisine because of series of years. One of the most important is the age of Mathias Hunyadi, he had Italian wife, called Beatrice having good knowledge on famous Italian cuisine. In this time Hungarian people met with spices, onion, garlic, pasta (Horváth, 2009). During the history, Turkish, Asian, Russian, German effects were influenced on the national gastronomy and Hungarians were very proud of hospitality.

The basic philosophy of Hungarian cuisine is based on the harmonic levelling of contrasting tastes than in the early time, levelled the sweet and sour tastes in harmony. For this purpose they used fresh plants like tarragon and golden cress or spices like ginger, pepper, and saffron (Cey-Bert, 2000).

The traditional Hungarian cuisine has slowly changed during centuries. New ingredients appeared (paprika, tomato, and potato) and frying and coating methods became preferred among the various kitchen technologies.

In the 20th century, political and economic situation had negative effect on gastronomy, it is called as a standardized monotony.

A few decades ago, the rest of the world started to focus on top quality instead of quantity and Hungarian chefs have had to face that we have not got as good reputation as we thought because our foods are not healthy and with no proper nutritional value. We have good local basic materials (meat, vegetables, wines) but we do not use because of the lower price of import from other EU's country. Nowadays there is a change in the system, there are two parts of gastronomy that can be forced: street food with bistro-style and slow food with fine-dinings. A lot of Hungarian consumers are not satisfied with this situation because their reaction and acceptability are slow, they believe in the previous practice. They have neofobia, they are afraid of new things. The smaller part with the new generation of chefs and youngs is able to use the new kitchen-technical methods, believes in special Hungarian raw materials (Mangalica, Balaton, Tisza fish, etc.), and wants to follow culinary trends.

Regarding food-related trends, one of the most important buzzwords of today was considered "health" by Töröcsik, the need for health during food purchases is becoming more and more important. Consumption of food that complies with this trend is nowadays generating social recognition. Another megatrend is emergence of morality, environmental awareness, and sustainability (Töröcsik, 2016). Regarding consumer behavior and these trends, Hungarian cuisine needs to be renewed.

\section{The Orange Wine Story}

According to our present knowledge, the cradle of wine culture of the world is located in South Caucasus, in the area of present day Georgia. In Georgia, seeds have been found which seem to be the seeds of cultivated 
grapes and can be dated around 6,000 BC (Phillips, 2001).

The ancient Georgian people used special clay pots, so called qvevri and put grapes into these vessels. After the long fermentation period, they pressed the grapes and put back into the amphores (Figure 1).

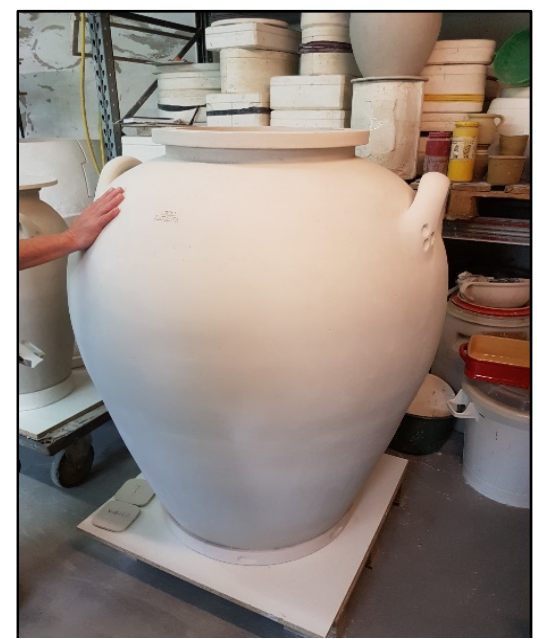

Figure 1. Amphore from Légli Pottery in Hungary. Source: Own editing.

There are various ideas and technologies regarding the implementation or legal regulations for orange wines. In 2013, the qvevri technology was inscribed on the UNESCO Representative List of the Intangible Cultural Heritage of Humanity (Unesco 8.COM 8.13 Description, 2013) and since then there have been many winemakers in Europe (Italian, Slovenian, Spanish, Hungarian) probing this strange technology (Figure 2) (Brincat, 2014).

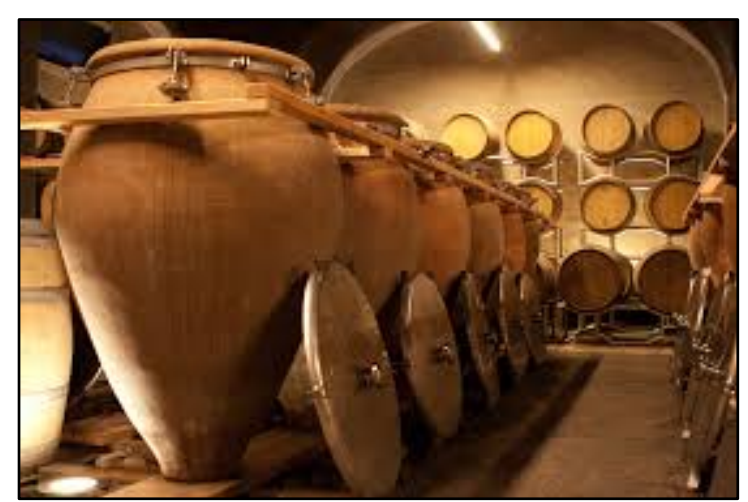

Figure 2. Foradori organic winery in Italy. Source: www.elisabettaforadori.com, photo by Foradori and Andrea Scaramuzza.

In previous work, the author collected the main characteristic features of Hungarian skin-contact, fermented white wines which are the following:

- The raw materials come from biodinamic viticulture;

- The natural-ness is very important; winemakers strive to use no more than a small amount of sulphur in the technology and the use of physical and chemical stabilizing agents is kept to a minimum or eliminated completely. In this way, one of the most important current consumer-trend, environmental consciousness, can be found in this wine-making method; 
- Orange wines are fashionable product in gastronomy;

- These wines are totally dry or semi-dry with high alcohol content;

- Their appearance is characterised by darker colour then white wines, ranging from orange through salmon top dark amber colours;

- They often have an extremely high price!

\section{Culinary Trends}

According to the Mintel British market research firm (Mintel, 2018), the global food consumption trends in 2018 are as follows:

- Trust in tradition: consumers look for modernized versions of traditional products, in terms of composition, flavor, and format;

- Reduction of food waste;

- Rise of plants: the increase in popularity of more natural, simple, and more flexible diets further enchances the spreading of vegetarian, vegan, and other plant-based formulas;

- Natural and ethical claims on global new food and drink product launches are on the rise;

- Mental balance and relaxation are very important fact;

- Nutritional value is high but quantity should be lower;

- Dishes with poor salt, sugar, and spice content.

Regarding orange wines, it can be said that the skin-contact fermented white wines meet the above described trends and value requirements. Grape raw materials come from organic farming, the technology and spririt of wine-making go back to the tradition, the use of sulfur is minimal in the case of wines and no chemical stabilizers are used for the preservation of the products. There is no polluting byproduct produced during the winemaking process. All these could be important elements of the favourable market positioning of orange wines.

\section{Materials and Methods}

In my survey, descriptive research methods were selected: sensory descriptive method and in-depth interviews.

\section{Sensory Descriptive Test: Profile Analysis-Wine Aroma Profile Test}

This method is one of the most complex descriptive sensory methods. Realization of the characteristics, 86 properties were examined through 17 wine-samples using 20 judges (two orange wine-makers, two wine-makers, nine university-students, two wine-sellers, one researcher, two sommeliers, and two chefs). According to the instruction of Ann C. Noble's Wine Aroma Wheel (Chen, Hambuchen, Rhodes, et al., 2014) the author made the aroma wheel of Hungarian orange wines. The wheel is a tool to learn about wines and learn to describe what feeling.

\section{Questioning Method: In-Depth Interviews}

László Ruprecht, President of SVÉT (association of the top restaurants of the countryside), creative chef of numerous restaurants and the Pannónia Gastro-Boat and László Angerman, sommelier, top sommelier of Hungary in 2016 and 2018 were chosen as the subject of author's expert in-depth interviews, because they are the prominent persons of Hungarian cuisine, they own extensive knowledge in the field of gastronomy, both food and wines too. 


\section{Results}

The collected skin-contact fermented Hungarian white wines can be followed in Table 1 .

Table 1

Hungarian Orange Wines Collected to the Sensory Descriptive Test

\begin{tabular}{|c|c|c|c|c|c|}
\hline $\begin{array}{l}\text { Serial } \\
\text { number }\end{array}$ & Name of the wine & Vintage & Grape-variety & Producer & Wine-region \\
\hline 1 & Anna Luca & 2015 & Cserszegi spicy & Zsolt Sándor & Bükki \\
\hline 2 & Furmint & 2015 & Furmint & Bálint Losonci & Mátrai \\
\hline 3 & Orange Chardonnay & 2015 & Chardonnay & Pannonhalma Abbey Winery & Pannonhalmi \\
\hline 4 & Orange Pinot Gris & 2015 & Pinot gris & Pannonhalma Abbey Winery & Pannonhalmi \\
\hline 5 & Orange Rhine Riesling & 2015 & Rhine riesling & Pannonhalma Abbey Winery & Pannonhalmi \\
\hline 6 & Orange Rhine Riesling & 2016 & Rhine riesling & Pannonhalma Abbey Winery & Pannonhalmi \\
\hline 7 & $\begin{array}{l}\text { Orange } \\
\text { Gewürztraminer }\end{array}$ & 2015 & Gewürztraminer & Balázs Káli & Balatoni \\
\hline 8 & Orange Zeta & 2017 & Zeta & Tokajbor-Bene Winery & Tokaji \\
\hline 9 & Orange Wine & 2015 & Linden leaf & Zoltán Demeter & Tokaji \\
\hline 10 & Welschriesling & 2015 & Welschriesling & Bálint Losonci & Mátrai \\
\hline 11 & Pinot Gris & 2015 & Pinot gris & Bálint Losonci & Mátrai \\
\hline 12 & Salto Mortale & 2015 & Grüner veltliner & László Jász Winery & Somló \\
\hline 13 & Tokaji Furmint & 2011 & Furmint & László Majoros & Tokaji \\
\hline 14 & Pinot Gris or what? & 2015 & Pinot gris & Nádas Winery & Etyek \\
\hline 15 & $\begin{array}{l}\text { Pinot Gris in Red } \\
\text { monkdom }\end{array}$ & 2014 & Pinot gris & Tarjányi Winery & Egri \\
\hline 16 & Zenit & 2015 & Zenit & Franz Weninger & Soproni \\
\hline 17 & Zsombor & 2014 & Furmint & Pannon Tokaj Ltd. & Tokaji \\
\hline
\end{tabular}

It was mapped out which winemakers produce orange wine in each wine-region.

There are two types of orange wines: one part is fresh with a fruity smell and taste $(1,7,8,9,12,14,16$, 17 samples) and the other $(2,3,4,5,6,10,11,13,15$ samples $)$ is more structured and combined with roasted characters.

Orange colour is not as basic as we thought, because there are special grape varieties such as Tramini and Pinot Gris which have more colour compounds in the berry-skin and can reach a more intensive "orange" colour but these are not as fruity as those varieties with less colour.

In Hungary, the 2015 vintage is the most productive year. Although there is no need for special weather circumstances to use that technology, we can declare that we need much sunny time during the summer, long autumn because the basic material needs much more sugar than normal case being able to keep and ferment for a long time in the amphores without any technological help. Year 2015 was a good vintage giving favourable parameters to orange wines. In this way, after a natural fermentation period, we have got high alcohol-content with a very little sugar (less than $10 \mathrm{~g} / \mathrm{l}$ ).

It can be said that the fresh, fruity grape-varietes such as Tramini or Pinot gris can collect much more body, dry-extracted contents with this technology and show a complex-matured side of possibility to use this kind of grape-varieties.

The result of sensory descriptive test can be seen in Figure 3 . 


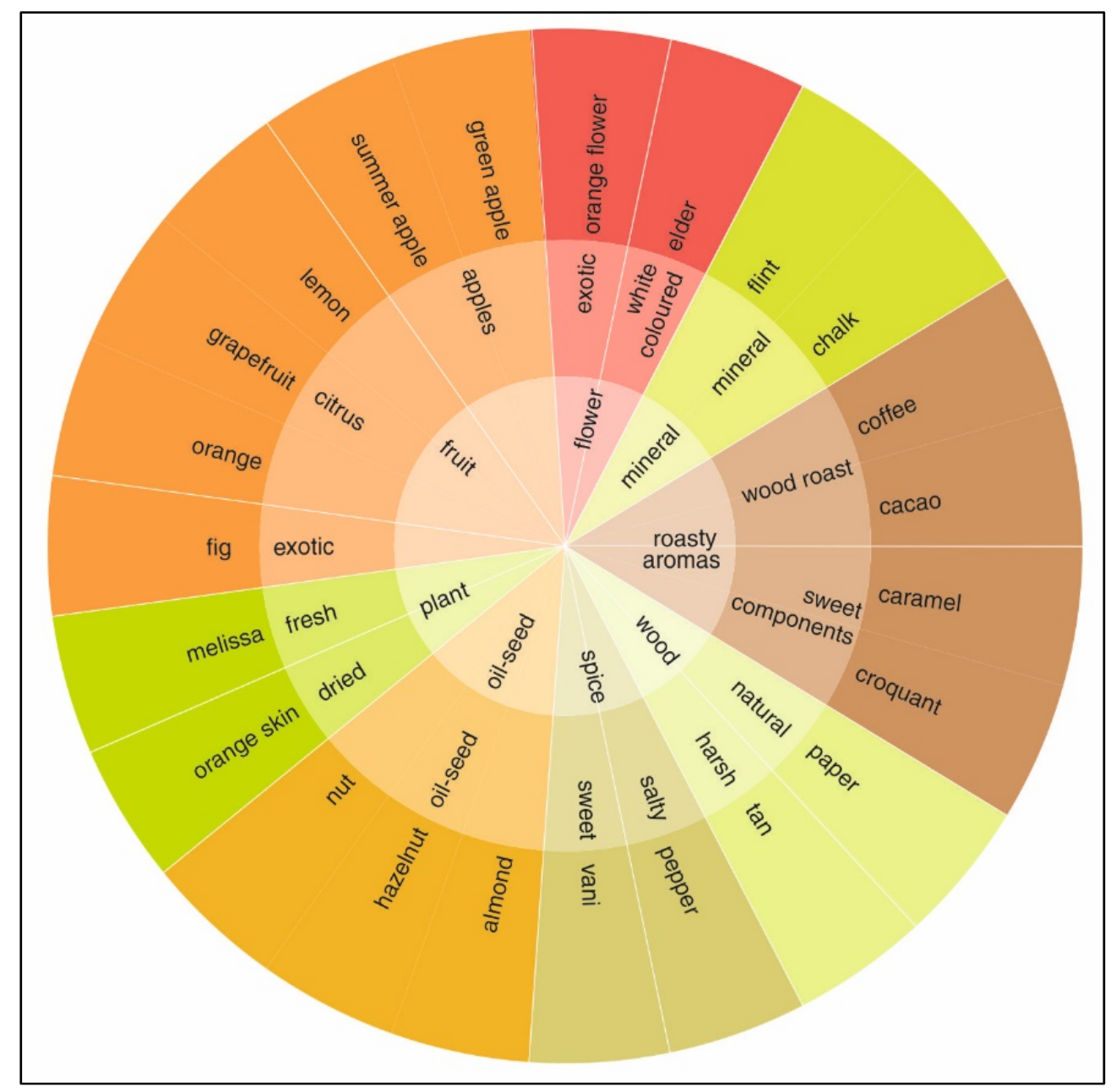

Figure 3. Hungarian orange wine aroma wheel.

Sensory characteristics like vanilla, roasted seeds, peanuts, orange peel, and pear are very important elements in both type of orange wines (fresh or aged). It can be said, the light red wine characters (tannins, vanilla, pepper) meet elegant and exotic features (croquant, green apple, grapefruit).

When we are looking for a food pair, with the aid of this wheel we can decide what type of characters we want to use, for eaxample in the case of a risotto with safranic, an orange wine will be better choice because orange flowers are suitable and present parameters in doing pair with food and drink. In opposite, a risotto with rosemary, an orange wine is not good beacuse it can be seen on the aroma wheel, that there is no ananas and strawberry character in them, in this way they do not work together.

The author has chosen a special character so called "the mediterranous orange imagine" and through this feature the author examined wines with ANOVA Single factor, the result can be seen in Table 2 .

The $p$-value is $p<0.01$, in this way we can declare that there is strongly significant difference between wines if we looking for the mediterraneous orange character as based on the name, these wines have darker tone and different spicy smell and taste than normal white wines and having different parameters. Next time standardization is avoidable being able to recognize the types of wines and find out other name than "Orange Wine" because it is quite misunderstood. 
Table 2

The Results of ANOVA Single Factor

\begin{tabular}{|c|c|c|c|c|c|c|}
\hline \multicolumn{7}{|l|}{ Summary } \\
\hline Groups & Count & Sum & Average & Variance & & \\
\hline Wine assessment & 17 & 64.15 & 3.773529 & 0.448474 & & \\
\hline Wine numbering & 17 & 153 & 9 & 25.5 & & \\
\hline \multicolumn{7}{|l|}{ ANOVA } \\
\hline Source of variation & $\mathrm{SS}$ & df & MS & $F$ & $p$-value & $F$ crit \\
\hline Between groups & 232.186 & 1 & 232.186 & 17.89592 & 0.000183 & 4.149097 \\
\hline Within groups & 415.1756 & 32 & 12.97424 & & & \\
\hline Total & 647.3615 & 33 & & & & \\
\hline
\end{tabular}

As a result of the in-depth interviews, the following statements can be highlighted:

- The gastronomy needs renewed conceptions, new technologies, new raw materials but we have to find the equilibre. Orange wines are new but unknown, in this way it is very difficult to use well. The story-telling has very important role because Hungarians' neofobia, to teach is unavoidable.

- Most people interest in orange wines because of its naturalness and uniqueness, that is why we have to look for place for them in menus. It is difficult to formulate a specific orange wine recommendation for positioning in fine-dining, the appropriate counterpart of the specific orange wine can be found, considering the vintage, the grape-variety, the terroir, and the processing tools, by trial and error and sensory testing, and the result can be any dish from an appetizer to a dessert.

- Phenolic components, roast and vanilla, herbs characters are very useful points to find place for orange wines. Hungarian cuisine likes safranic, paprika, coffee, in this way making pair with a traditional food, for example a renewed goulash (Figure 4), what is not a soup but a dish with same tastes then the original goulash.

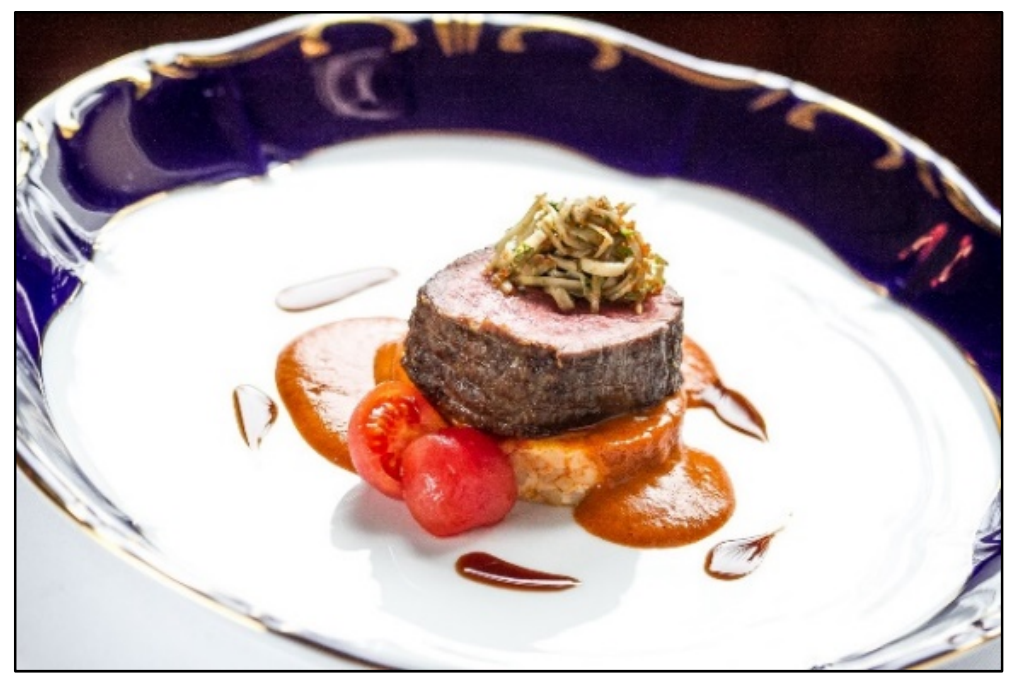

Figure 4. "Mágnás gulyás” in Gundel Restaurant. Source: www.welovebudapest.com, photo by László Balkányi.

The most important features, as positioning factors of the orange wines are:

- Orange wine making has a "story", based on ancient thousands of years of tradition;

- Naturalness, there is no chemical stabilizing agent, sulfur level is low or eliminated completely;

- Healthy because of phenolic content being able to reduce oxidization; 
- Orange wines can be a specaility in a food-wine pair of a local restaurant, where costumers can participate in an inmemorable experience and would come here next time too to taste again.

\section{Conclusions}

Followers of today's modern gastronomic trends promote the healthy, natural, amazing, and sustainable foods, they are important players in the national gastrotourism. New trends from foreigner countries will become more and more popular and recognized in Hungary. If more layers of our society realize the difference between quality and quantity of meals and food, then market demand will bring new gastronomy trends, new types of interesting restaurants, and more culinary development. In this way, renewed conceptions are necessary with new kitchen technical methods with new foods. It can be said, orange wines have more reputations than its taste, consumers will like not just for taste but its story and they should be a member of an innovative food-drink pair. To realize it, there is a need to have knowledges on its aroma components what can be studied by using aroma wheel.

\section{References}

Bene, Z., \& Piskóti, I. (2017): Assessment of orange wines in the light of new food consumption trends. Journal of Food Investigation, 63(4), 1790-1811.

Brincat, I. (2014). Foradori: A great winemaker from the Dolomites. Available at https://elisabettaforadori.com (Acquired: 21.03.2018)

Cey-Bert, R. (2000). Hungarian gastronomy ont he revival in Gold Hungarian gastronomy, Kner Nyomda, Gyomaendrőd, p. 5.

Chen, B., Hambuchen, L., Rhodes C., \& Crawford, A. (2014). Wineinformatics: Applying data mining on wine sensory reviews. Processed by the Computational Wine Wheel, Conference paper. DOI: 10.1109/ICDMW.2014.149

Horváth, P. (2009). Táplálkozástan, Képzőművészeti Kiadó Kft., Kaposvár, $93-96$ (old).

Mintel. (2018). Global food \& drink trends 2018. Available at https://downloads.mintel.com/private/UtlXg/files/628089 (Acquired: 17.02.2018)

Phillips, R. (2001). A short history of wine. London: Allen Lane.

Töröcsik, M. (2016). A fogyasztói magatartás új tendenciái, Vezetéstudomány, XLVII. évf. 2016. Marketingtudomány különszám.

Tusor, A., \& Sahin-Tóth, G. (2005). Gasztronómia, Étel- és italismeret, Kereskedelmi és Idegenforgalmi Továbbképző, Budapest, 17 (old).

Unesco 8.COM 8.13 Description. (2013). Ancient Georgian traditional Qvevri wine-making method. Available at https://ich.unesco.org/en/RL/ancient-georgian-traditional-qvevri-wine-making-method-00870 (Acquired: 29.04.2018) 